\title{
Screening and identification of lactic acid bacteria strains with high acid-producing from traditional fermented yak yogurt
}

\author{
Xiaoyong Chen ${ }^{1,2,3, \#}$, Xin Zhao ${ }^{3,4, \#}$, Yu Qian ${ }^{3,4}$, Jian $\mathrm{Li}^{5,6}$, Lianhong Chen ${ }^{5,6}$, Juan Chen ${ }^{6}$, Yu Zhang ${ }^{1,2}$ \\ and Huayi Suo ${ }^{1,2, a}$ \\ ${ }^{1}$ College of Food Science, Southwest University, 400715, Chongqing, China \\ ${ }^{2}$ Chongqing Engineering Research Center of Regional Food, 400715, Chongqing, China \\ ${ }^{3}$ Chongqing Collaborative Innovation Center for Functional Food, Chongqing University of Education, 400067, \\ Chongqing, China \\ ${ }^{4}$ Department of Biological and Chemical Engineering, Chongqing University of Education, 400067, Chongqing, \\ China \\ 5 Institute of Qinghai-Tibetan Plateau, Southwest University for Nationalities, 610041, Chengdu, China \\ ${ }^{6}$ College of Life Science and Technology, Southwest University for Nationalities, 610041, Chengdu, China
}

\begin{abstract}
A total of 57 strains of lactic acid bacteria (LAB) were isolated and purified from traditional fermented Yak Yogurt in Hongyuan-Sichuan and Yangbajing-Tibet. The strains with high acid-produced were screened by soluble calcium circle and titratable acidity determination. The five strains, 7-1, 22-1, 28-1, 34-1 and 62-1, possessed the high acidproducing and the value of titratable acidity is 196.2, 191.1, 192.2, 194.8 and $200.2 \mathrm{~T}$ respectively. Based on 16S rDNA sequence analysis, 22-1 was identified as Lactococcus lactis subsp. lactis, 28-1 as Lactobacillus casei, 34-1 as Lactobacillus fermentium, 7-1 and 62-1 as Enterococcus durans. This study could provide the evidence for researching fermentation strains to improve yogurt quality.
\end{abstract}

\section{Introduction}

Lactic acid bacteria refer to a group of bacteria with the capacity to ferment carbohydrate to generate lactic acid. It is a main fermentative strain to ferment traditional fermented foods like dairy product, pickle and fermented sausage etc. Lactic acid bacteria generates flavor substances such as micromolecule aldehyde, acid and ester etc. through fermenting saccharides to promote the formation of traditional fermented food's flavor, which plays a great importance in fermented food[1, 2]. In the fermentation process of dairy product, the acid-producing ability of lactic acid bacteria is a key factor to measure the quality of dairy product [3]. Bian Lihong and others [4] researched and found that the acid-producing ability of lactic acid bacteria in different brands of plain yogurt is closely related to the

\footnotetext{
${ }^{\text {a }}$ Corresponding author: birget@swu.edu.cn, ${ }^{\#}$ Co-first author

This work was partly supported by Special Fund for Agro-scientific Research in the Public Interest (201203009), Special Fund of Chongqing People's Livelihood and Technology Innovation (cstc2015shmszx 80021) and Fundamental Research Funds for the Central Universities(XDJK2016E109).
} 
separation of curd and whey in yogurt. In addition, the lactic acid bacteria with a high acid-producing ability can not only shorten curd time and enhance productivity but also perfect yoghourt's texture and improve the quality of yoghourt etc. Consequently, to select the lactic acid bacteria with a high acidproducing ability has an important significance for improving the quality of yoghourt. At present, to select the lactic acid bacteria with a high acid-producing ability among traditional fermented foods has gotten a wide attention from many domestic and overseas scholars. Zhang Heping etc. [5] researched the characteristics of acid production for the lactic acid bacteria separated from natural fermented dairy product, from which a Streptococcus thermophilus with short curd time, high rate of acid production and weak post-acidification ability is obtained. Ma Yuxiao etc. [6] get three lactic acid bacteria with high curd speed, high acid-producing ability and fine curd quality through the screening from dzo yoghourt. In addition, Carafa etc. [7] researched the experiment on glycometabolism, acidification ability and acid and bile salt tolerance etc. of lactic acid bacteria in natural fermented cheese of Alps, the selected lactic acid bacteria from which can be applied in the production of fermented dairy product. The good curd quality in traditional yak yoghourt has shown that there are lactic acid bacteria with a high performance. The special growing environment and the narrow distribution range of yak have limited the research of lactic acid bacteria in traditional fermented yak yogurt.

Our country is the headstream of yak in the world. Yak resource is very rich in Qinghai-Tibet Plateau, where herdsman adopts traditional handicraft and natural fermentation method to make yak yogurt $[8,9]$. It is an indispensable necessity in herdsman's daily life, as well as a traditional featured delicious food in this area. The unique geographical environment, climatic condition, Tibetan herdsman's scattered community and nomadic pasture pattern have together formed the special resource pool of lactic acid bacteria in Qinghai-Tibet Plateau, which offers a guarantee for selecting the lactic acid bacteria with high fermentative capability. This research screens the lactic acid bacteria in traditional fermented yak yogurt and evaluates its acid-producing ability to provide the reference for better using fine strains and improving the quality research of traditional fermented yak yogurt.

\section{Material and method}

\subsection{Reagents}

\subsubsection{Bacterial source}

Fifty seven lactic acid bacteria strains separated from the traditional yak yogurt in Hongyuan of Sichuan and Yangpachen of Tibet are kept in store by College of Food Science, Southwest University.

\subsubsection{Reagent}

MRS broth, agar from Beijing Solarbio Science and Technology Ltd. Sodium hydroxide, calcium carbonate analytically pure from Chengdu Kelong Chemical Reagent Factor. $\lambda$ DNA/HindIII, $6 \times$ DNA Loading Buffer, 100 bp DNA Ladder, $2 \times$ Taq PCR MasterMix, bacterial genome DNA extraction kit (DP302) from Tianjin Biotech (Beijing) Co., Ltd. forward primer 27F (5AGAGTTTGATCCTGGCTCA-3), reverse primer 1495R (5-CTACGGCTACCTTGTTACGA-3) compounded by Sangon Biotech (Shanghai) Co., Ltd.

\subsection{Instrument and equipment}

Storm Gradient PCR, S1000 Thermal Cycler and Mini-Sub Cell GT from American Bio-Rad Company, Centrifugal machine 8510 from Germany Eppendorf Company, Water-Jacket Thermostatic Constant Incubator, GHP-9160 from Shanghai Keelrein Scientific Instrument Co., Ltd. Clean bench, 
SW-CJ-2F from Suzhou Antai Airtech Co., Ltd. pH meter,PHS-3C from INESA Analytical Instrument Co., Ltd.

\subsection{Methodology}

\subsubsection{Preliminary screening of lactic acid bacteria with high acid-producing ability}

In clean bench, add $1.5 \%$ sterile $\mathrm{CaCO}_{3}$ into the sterile MRS medium. Then shake to make $\mathrm{CaCO}_{3}$ well mixed. In this process, bubble should be avoided. When it is cooled to about $46^{\circ} \mathrm{C}$, pour it into the plate immediately. After solidification, it is as standby application. Select an appropriate dilution of bacterial liquid to make spread plate cultivation at $37^{\circ} \mathrm{C}$ for $24 \mathrm{~h}$. Finally, make the preliminary judgment for the acid-producing ability of experimental bacteria through the size of $\mathrm{CaCO}_{3}$ lysis zone and bacterial colony to select the bacterial strain with an obvious transparent zone as the alternative bacterium with high acid-producing ability.

\subsubsection{Determination of acidity for lactic acid bacteria with high acid-producing ability}

Inoculate the cultivated bacterial liquid into MRS fluid medium as per $2 \%$ inoculum size. Measure the titration acidity after cultivating for $48 \mathrm{~h}$ at $37^{\circ} \mathrm{C}$. Take $10 \mathrm{~mL}$ nutrient solution into $150 \mathrm{~mL}$ erlenmeyer flask. Then add $20 \mathrm{~mL}$ water after boiled and cooled and 2 drops of phenolphthalein indicators to make well mixed. Use acidometer to indicate end point and $0.1 \mathrm{~mol} / \mathrm{L} \mathrm{NaOH}$ standard solution to titrage to $\mathrm{pH}, 8.2$. Record the volume of $\mathrm{NaOH}$ standard solution consumed. Finally calculate the acidity of nutrient solution, which will be indicated by Thorner degrees $\left({ }^{\circ} \mathrm{T}\right)[10]$.

\subsubsection{Analysis on identification and phylogenetic tree of lactic acid bacteria with high acid- producing ability}

Preparation of DNA template: extract genome DNA (template) of lactic acid bacteria with high acidproducing ability by the method in the specification of DNA extraction kit. Use $0.7 \%$ agarose gel electrophoresis to make the test.

PCR amplification: PCR reaction system is $25 \mu \mathrm{L}$. Template is $1 \mu \mathrm{L}$. Primers, $27 \mathrm{~F}$ and $1495 \mathrm{R}$ are $1 \mu \mathrm{L}, 2 \times$ Taq PCR MasterMix $12.5 \mu \mathrm{L}$ respectively, complemented to $25 \mu \mathrm{L}$ through adding sterile ultrapure water. PCR reaction conditions include $94^{\circ} \mathrm{C} 5 \mathrm{~min}, 94^{\circ} \mathrm{C} 40 \mathrm{~s}, 55^{\circ} \mathrm{C} 40 \mathrm{~s}$ and $72^{\circ} \mathrm{C} 1 \mathrm{~min}$, totaling 35 cycles as well as $72^{\circ} \mathrm{C} 10 \mathrm{~min}$. After the reaction is finished, take $5 \mu \mathrm{L}$ PCR products to make the test through $1.5 \%$ agarose gel electrophoresis.

Sequencing comparison: send PCR products to BGI Science and Technology Ltd. to make sequencing. The sequencing data is submitted to GenBank of NCBI. Use Blast program to search the sequence with maximal homology, and finally determine the species of lactic acid bacteria with high acid-producing ability.

Analysis on phylogenetic tree: take 10 kinds of 10 lactic acid bacteria's gene sequences in the same segments from GeneBank database. Use Alignment program in Clustalx1.83 software to make multi-sequencing matching comparison for the tested sequences and the reference sequences obtained from BLAST searching. Then use Kimura 2-parameter mode in MEGA5.0 software to calculate genetic distance. The phylogenetic tree of homologous sequence to separate lactic acid bacteria is constructed by neighbor-joining method. Each branch of phylogenetic tree adopts bootstrap method to make confidence coefficient test. The bootstrap data set is 1000 [11-13].

\section{Results and analysis}

\subsection{Preliminary screening results of high acid produced lactic acid bacteria}


Table 1 and Figure 1 show that the calcium-dissolving zones of 17 lactic acid bacteria are found not obvious. 30 lactic acid bacteria can generate calcium-dissolving zone. But the transparent zones are different to some extent for different bacterial strains.

Table 1. The situation of lactic acid bacteria produced transparent circle.

\begin{tabular}{|c|c|c|c|c|c|c|c|c|}
\hline $\begin{array}{c}\text { Serial } \\
\text { No. }\end{array}$ & No. & $\begin{array}{c}\text { Transparent } \\
\text { circle size }\end{array}$ & $\begin{array}{c}\text { Serial } \\
\text { No. }\end{array}$ & No. & $\begin{array}{c}\text { Transparent } \\
\text { circle size }\end{array}$ & $\begin{array}{c}\text { Serial } \\
\text { No. }\end{array}$ & No. & $\begin{array}{c}\text { Transparent } \\
\text { circle size }\end{array}$ \\
\hline 1 & 27 & + & 20 & $4-1$ & + & 39 & $25-1-1$ & ++ \\
\hline 2 & 31 & - & 21 & $4-2-2$ & ++ & 40 & $25-1-2$ & ++ \\
\hline 3 & $32-2$ & ++ & 22 & $5-1$ & ++ & 41 & $25-2$ & + \\
\hline 4 & 37 & - & 23 & $6-1$ & + & 42 & $26-1$ & - \\
\hline 5 & $38-2$ & - & 24 & $6-2$ & + & 43 & 27 & ++ \\
\hline 6 & $41-1$ & - & 25 & $7-1$ & ++ & 44 & $27-2$ & ++ \\
\hline 7 & $43-2$ & - & 26 & $7-2$ & ++ & 45 & $28-1$ & ++ \\
\hline 8 & 54 & ++ & 27 & $12-1$ & ++ & 46 & $32-1-1$ & ++ \\
\hline 9 & 55 & - & 28 & 16 & + & 47 & $32-1-2$ & ++ \\
\hline 10 & $57-2$ & + & 29 & $17-2$ & ++ & 48 & $34-1$ & ++ \\
\hline 11 & 58 & - & 30 & $18-1-1$ & ++ & 49 & 40 & ++ \\
\hline 12 & 60 & - & 31 & $18-1-2$ & ++ & 50 & $41-1$ & ++ \\
\hline 13 & 64 & + & 32 & $18-2$ & + & 51 & $41-2$ & + \\
\hline 14 & 71 & - & 33 & $18-3$ & ++ & 52 & $42-1$ & + \\
\hline 15 & 77 & ++ & 34 & $19-1$ & ++ & 53 & $53-1$ & ++ \\
\hline 16 & 88 & ++ & 35 & $21-1$ & + & 54 & $53-2$ & + \\
\hline 17 & 89 & - & 36 & $21-2$ & ++ & 55 & $53-3$ & + \\
\hline 18 & $3-1-1$ & ++ & 37 & $22-1$ & ++ & 56 & $62-1$ & ++ \\
\hline 19 & $3-1-2$ & + & 38 & $23-1$ & ++ & 57 & $67-1$ & + \\
\hline
\end{tabular}

Note: "++", strong transparent circle, "+", weak transparent circle, "-", no transparent circle.

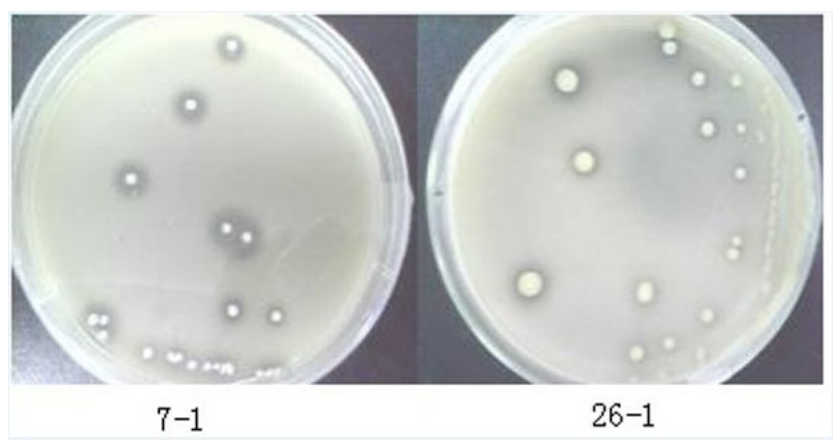

Figure 1. The lactic acid bacteria produced transparent circle in MRS calcium carbonate medium.

\subsection{Acidity determination results of high acid produced lactic acid bacteria}

Table 2 shows that the acid-producing range of experimental bacterial strain is from 69.2 to $200.2^{\circ} \mathrm{T}$, among which the acid-producing contents of No.7-1, 22-1, 28-1, 34-1 and 62-1 bacterial strains are higher. The titration acidities are 196.2, 191.1, 192.2, 194.8 and 200.2 o T respectively. The acidproducing contents of experimental bacterial strains researched by Liu Zhenming etc. [14] are from $64.4^{\circ} \mathrm{T}$ to $294.2^{\circ} \mathrm{T}$, and the ones researched by Zhang Lanwei etc. [15] from $44.35^{\circ} \mathrm{T}$ to $57.65^{\circ} \mathrm{T}$. Compared with the screening results made by other scholars, the lactic acid bacteria with bacterial strains No. 7-1, 22-1, 28-1, 34-1 and 62-1 have a higher acid-producing ability. Under the same 
culture medium and condition, the diffident acid-producing ability of different strains shows that difference exists between the acid-producing ability of bacterial strain metabolism's carbohydrate and its acid resistance.

Table 2. Acidity determination results of high acid produced lactic acid bacteria after screening.

\begin{tabular}{|c|c|c|c|c|c|c|c|c|}
\hline $\begin{array}{c}\text { Serial } \\
\text { No. }\end{array}$ & No. & Acidity $\left({ }^{\circ} \mathrm{T}\right)$ & $\begin{array}{c}\text { Serial } \\
\text { No. }\end{array}$ & No. & Acidity $\left({ }^{\circ} \mathrm{T}\right)$ & $\begin{array}{c}\text { Serial } \\
\text { No. }\end{array}$ & No. & $\begin{array}{c}\text { Transparent } \\
\text { circle size }\end{array}$ \\
\hline 1 & $32-2$ & $91.9 \pm 0.36$ & 11 & $17-2$ & $128.8 \pm 1.08$ & 21 & 27 & $103.3 \pm 0.53$ \\
\hline 2 & 54 & $91.8 \pm 0.53$ & 12 & $18-1-1$ & $104.8 \pm 0.26$ & 22 & $27-2$ & $69.2 \pm 0.79$ \\
\hline 3 & 77 & $98.0 \pm 0.20$ & 13 & $18-1-2$ & $105.9 \pm 0.35$ & 23 & $28-1$ & $192.2 \pm 0.30$ \\
\hline 4 & 88 & $87.8 \pm 0.26$ & 14 & $18-3$ & $104.0 \pm 0.26$ & 24 & $32-1-1$ & $129.7 \pm 0.36$ \\
\hline 5 & $3-1-1$ & $86.8 \pm 0.46$ & 15 & $19-1$ & $103.2 \pm 0.30$ & 25 & $32-1-2$ & $104.0 \pm 0.26$ \\
\hline 6 & $4-2-2$ & $102.9 \pm 0.36$ & 16 & $21-2$ & $110.2 \pm 0.36$ & 26 & $34-1$ & $194.8 \pm 0.79$ \\
\hline 7 & $5-1$ & $134.2 \pm 0.89$ & 17 & $22-1$ & $191.1 \pm 0.20$ & 27 & 40 & $100.4 \pm 0.44$ \\
\hline 8 & $7-1$ & $196.2 \pm 0.26$ & 18 & $23-1$ & $177.8 \pm 0.23$ & 28 & $41-1$ & $128.0 \pm 0.26$ \\
\hline 9 & $7-2$ & $145.3 \pm 0.36$ & 19 & $25-1-1$ & $103.0 \pm 0.70$ & 29 & $53-1$ & $94.2 \pm 0.44$ \\
\hline 10 & $12-1$ & $122.4 \pm 0.30$ & 20 & $25-1-2$ & $153.8 \pm 0.26$ & 30 & $62-1$ & $200.2 \pm 0.46$ \\
\hline
\end{tabular}

\subsection{Identification of high acid produced lactic acid bacteria}

Figure 2A shows that genome DNA of bacterial strain is in around $23130 \mathrm{bp}$, strip neat and luminosity obvious, which means the extraction effect of genome DNA is good. The target fragment after PCR amplification gets close to $1500 \mathrm{bp}$ (Figure 2B), no tailing phenomena in strip, clear and bright, and no strip in negative control, which means PCR amplification succeeds with a better effect.

(A)

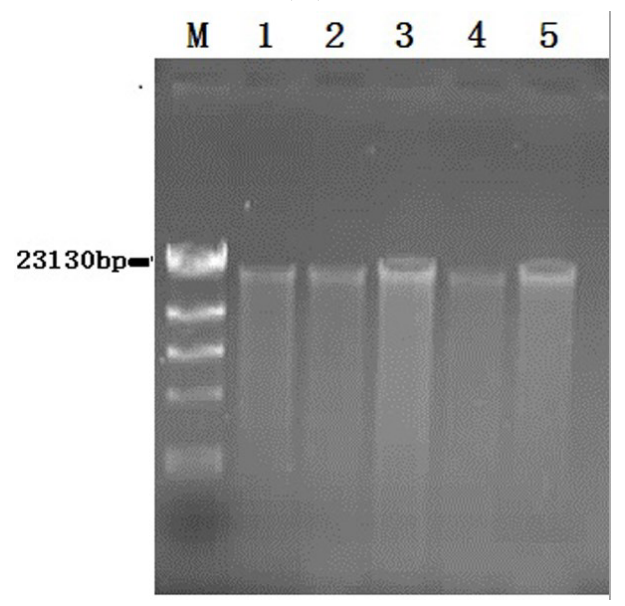

(B)

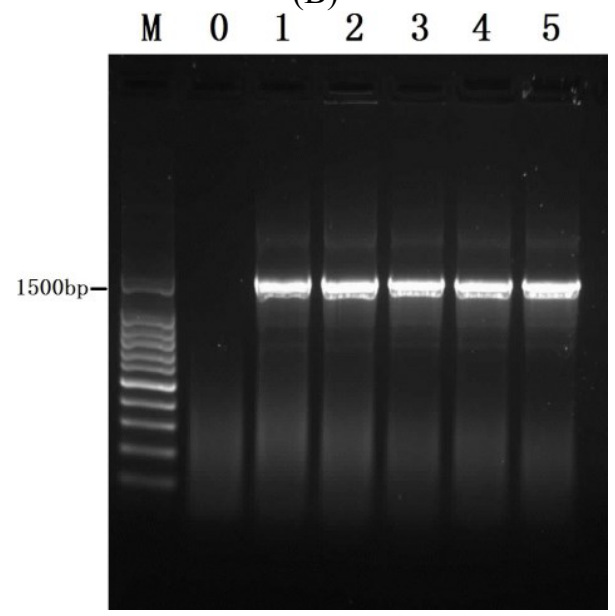

Figure 2. Agarose gel electrophoresis of genomic DNA (A) and PCR products (B).

Traditional fermented yak yogurt is a dairy product with unique flavor, co-fermented by complex microflora taking actic acid bacteria and saccharomycetes as main bacteria and microorganism. At present, it is found through research that its fermentation microorganism [16] is mainly composed by Enterococcus faecium and Enterococcus durans in Enterococcus, Lactobacillus casei, Lactobacillus plantarum, Lactobacillus bulgaricus, Lactobacillus fermentium and Lactobacillus helveticus in Lactobacillus and Leuconostoc mesenteroides subsp. mesenteroides as well as Streptococcus thermophilus etc. Traditional fermented yak yogurt is characterized by high acidity. The acid generally $[17,18]$ can reach to $198.7^{\circ} \mathrm{T}$. The research finds various lactic acid bacteria including Enterococcus faecium, Enterococcus durans, Lactobacillus casei, Lactobacillus paracasei, Lactobacillus fermentium and Lactococcus lactis as well as Lactococcus lactis subsp. lactis and Streptococcus thermophilus etc. contribute to the formation of yak yogurt's acid and flavor. Table 3 shows the experiment also 
has verified that Enterococcus durans, Lactococcus lactis subsp. lactis, Lactobacillus casei and Lactobacillus fermenti play a significance role in the formation of yak yogurt's acid. Although enterococcus durans have not been recorded in the list of bacteria used in our country's food industry, it is an important composition in microflora of traditional fermented yak yogurt. It has a high acid-producing ability, so its effect is more significant in the quality formation of traditional fermented yak yogurt.

Table 3. Identification results of high acid produced lactic acid bacteria

\begin{tabular}{|c|c|c|}
\hline No. & Similarity(\%) & Latin name \\
\hline $7-1$ & 100 & Enterococcus durans \\
\hline $22-1$ & 100 & Lactococcus lactis subsp. lactis \\
\hline $28-1$ & 100 & Lactobacillus casei \\
\hline $34-1$ & 100 & Lactobacillus fermentium \\
\hline $62-1$ & 100 & Enterococcus durans \\
\hline
\end{tabular}

\subsection{Phylogenetic tree analysis}

Figure 3 shows that different genera of lactic acid bacteria are in their own branch. The branch length represents the degree of species evolution. In cladogram, Lactococcus, Leuconostoc, Galactococcus and Lactobacillus are included. The bacterial strains with No.7-1 and 62-1 are determined as Enterococcus durans to their 100\% bootstrap value. In phylogenetic tree, they are determined as Enterococcus durans. Both of them have a close genetic relationship. Meanwhile, the bacterial strain with No. 22-1 and Lactococcus lactis subsp lactis are classified into a group due to their $100 \%$ bootstrap value, determined as Lactococcus lactis subsp. lactis. It is known through the topological structure of cladogram that the genetic relationship between Lactococcus and Enterococcus is closer. But it has a distant genetic relationship with Lactobacillus and Leuconostoc. The bacterial strains with No. 28-1 and 34-1 are in Lactobacillus branch, having a closer genetic relationship. In phylogenetic tree, they are classified into a group with Lactobacillus paracasei, Lactobacillus casei, and Lactobacillus plantarum as well as Lactobacillus fermentium. Among them, the bacterial strain with No. 28-1 has the same bootstrap value as Lactobacillus casei and Lactobacillus paracasei. This is because Lactobacillus casei and Lactobacillus paracasei have a very close generic relationship. No. 34-1 bacterial strain and Lactobacillus fermentium are classified into a group due to their $100 \%$ bootstrap value, determined as Lactobacillus fermentium. The analysis result of phylogenetic tree and the result identified by $16 \mathrm{~S}$ rDNA method show that 16S rDNA method is feasible, and the result, reliable.

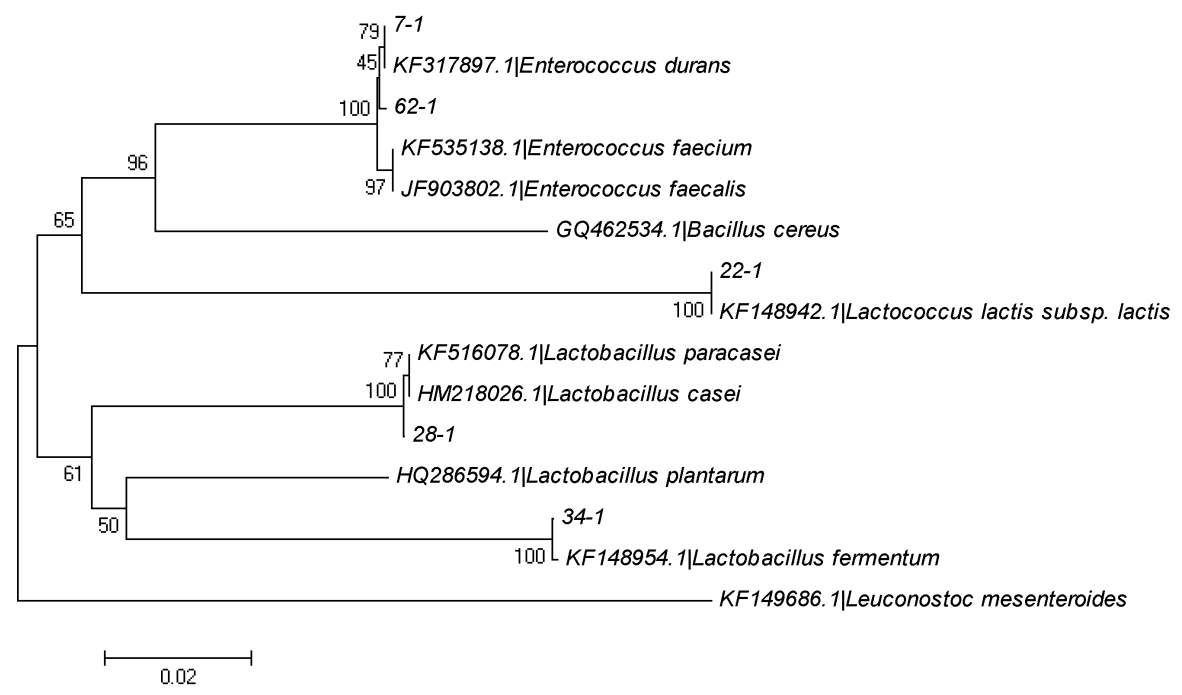

Figure 3. Phylogenetic tree of lactic acid bacteria rDNA 16S sequence. 


\section{Conclusion}

In this research, the lactic acid bacteria with high acid-producing ability in traditional fermented yak yogurt is screened and selected by calcium-dissolving zone method and through determination of titration acidity. The research shows the abilities of different bacterial strains in yak yogurt to generate calcium-dissolving zone are different. The acid-producing abilities are also different. The acidity is between 69.2 and $200.2 \mathrm{o}$ T. Among them, the bacterial strains with No. 7-1, 22-1, 28-1, 34-1 and the bacterial strain with No. 62-1 have a higher acid-producing ability. After cultivating for $48 \mathrm{~h}$ at $37^{\mathrm{OC}}$, titration acidities are 196.2, 191.1, 192.2, 194.8 and 200.2 o T respectively. No. 22-1 bacterial strain is identified as Lactococcus lactis subsp. lactis, No. 28-1 bacterial strain as Lactobacillus fermentium, and the bacterial strains with No. 7-1 and 62-1 as Enterococcus durans through 16S rDNA sequence analysis. Although Enterococcus durans have not been recorded in the list of bacteria used in our country's food industry, it is an important composition in microflora of traditional fermented yak yogurt. The experimental result shows that it has a high acid-producing ability, and playing an important role in the formation of flavor and quality of traditional fermented yak yogurt.

\section{References}

1. T.Q. Zhang, Z.N. Yang, B.H. Kong, Food Sci 637-642, 29 (2008).

2. X. Xin, G. Song, X.H. Zhou, J.W. Zhao, L. Chen, Q.P. Ge, W.X. Ping, J. Chinese Inst. Food Sci. Technol. 202-207, 14 (2014).

3. H. Qin, X. Liang, W.B. Zhang, Y. Zhang, L. Mi, Food Sci. 241-246, 34 (2013).

4. L.H. Bian, Y. Wang, Y.T. Zhang, L.N. Qu, Guangdong Agri. Sci. 128-130, 39 (2012).

5. H.X. Chen, L.L. De, Y. Ren, D.L. Zhang, Y.R. Yang, W.J. Liu, H.P. Zhang, J. Dairy Sci. Technol. $1-5,2015(2015)$.

6. H. Tian, X.P. Zhang, Y.L. Yan, Food Sci. 152-156, 31 (2010).

7. I. Carafa, T. Nardin, R. Larcher, R. Viola, K. Tuohy, E. Franciosi, Food Microbiol. 123-132, 48 (2015).

8. C.S. Wu, C. Shu, J. Li, Y. Qian, H.Y. Suo, Food Ind. 129-133, 33 (2012).

9. Y.W. Wang, C.M. Zhang, H.Y. Suo, H. Yue, J. Li, C. Tang, Sci. Technol. Food Ind. 184-187, 35 (2014)

10. C.X. Liu, Jiangsu J. Prev. Med. 69-70, 19 (208).

11. N.A. El-Naggar, S.A. Haroun, E.A. Oweis, A.A. Sherief, Prep. Biochem. Biotechnol. 712-729, 45 (2015).

12. K. Tamura, D. Peterson, N. Peterson, G. Stecher, M. Nei, S. Kumar, Mol Biol Evol. 2731-2739, 28 (2011).

13. S. Ennahar, Y. Cai, Y. Fujita, Appl. Environ. Microbiol. 444-451, 69 (2003).

14. Z.M. Liu, Y.Y. Wang, J. Dairy Sci. Technol. 169-172, 33 (2010).

15. C.L. Ma, L.W. Zhang, Sci. Technol. Food Ind. 189-190, 31 (2010).

16. L.V. McFarland, Clin. Infect. Dis. 85-90, 60 (2015).

17. Z. Luo, Y.G. Shi, L. Yu, B.Z. Han, China Brew. 40-41, 2005 (2005).

18. J. Xu, Y.Y. Yun, W.Y. Zhang, Y.D. Shao, B. Menghe, H.P. Zhang, China Dairy Ind. 23-27, 34 (2006). 